hygrometer has been developed for measuring the humidity of the stratosphere in investigations on fall-out.

In plasma physics and fusion research the main problems are still to identify, understand and control the many instabilities which prevent magnetic fields from confining extremely hot ions and electrons for more than a relatively brief moment. While these instabilities remain as a potential source of trouble in closed systems, there are now indications that they can be overcome in the open-ended magnetic traps. The programme also includes two experiments in 'Minimum $B$ ' geometry designed to see if the same freedom from interchange instabilities noted by Ioffe at the Kurchatov Institute will apply at higher plasma densities and with different methods of plasma injection. Besides investigations with a cusped field trap and a theatron trap, containmont with closed lines of force has been investigated and basic investigations made on plasma itself, particularly the propagation characteristics of the wide variety of wave motions which a magnotized plasma can support, and also the processes which can arise from collision between its constituent particles. At the Wantage Research Laboratory the feasibility of radioisotope $X$-ray fluorescence analysis for on-stream assay of zinc in zinc-lead ores has been investigated in co-operation with the Department of Scientific and Industrial Research, while invostigations bearing on health and safety have led to the development and manufacture of a personal neutron dosimeter. Studies of radioactivity in the human body continued using whole-body monitors and bioassay methods to determine the metabolic behaviour of nuclides, and continued physico-chemical study of chelating agents confirmed that diethylenetriamine pentacetic acid and triethylenetetramine hexacetic acid assist the removal of plutonium from the human body, but more effective and less toxic compounds are being sought.

The Reactor School programme at the Postgraduate Education Centre set up at Harwell on April 1, 1963, has been revised, and, after transfer of four of the more elementary courses, three new courses have been added: physics for engineers; language and technical writing; and a refresher course for senior technical executives. In collaboration with the European Nuclear Energy Agency a one-week residential course was given on health and safety aspects of radiation in industry for Trade Union officials. Of 379 students attending these courses, 340 were British and 39 from overseas, while 490 students attended a new series of postgraduate courses, and another 300 the 14 courses held in the Isotope School.

While the non-industrial staff fell over the year from 20,008 to 18,864 and industrial employees from 18,350 to 17,098 , the Authority made it clear to their staff that there is a large and continuing volume of work for the Authority, including civil research and development as well as production and processing. Some recruitment continued and the level will be raised in 1964, the need for young scientific and engineering graduates for research, design and development, and for training as future managers being mentioned, while 202 apprentices were recruited compared with 230 in the previous year.

The Authority has also published the tenth anniversary issue of Atom $\dagger$ including both an illustrated summary of the tenth annual report and an illustrated review of the developments during 1954-64.

† United Kingdom Atomic Energy Authority. Atom 1954/1964: an Atomic Energy Authority from April 1st, 1963, to March 31st, 1964. (Tenth Anniversary Issue.) Pp. 48. (London: H.M.S.O., 1964.) 28.6d.

\title{
THE SOUTH AFRICAN ATOMIC ENERGY BOARD
}

$\mathrm{T}$ HE South African Atomic Energy Board was set up in March 1949, and at first confined its operations almost exclusively to administrative procedures related to the mining, extraction and sale of uranium concentrates, the distribution and control of radioisotopes, mineral investigations, and the study of the production of heavy water. During 1957 detailed planning of an atomic energy resoarch and development programme for South Africa was started, and on September 5, 1959, the then Minister of Mines, Mr. J. de Klerk, announced the Government's acceptance of the proposed programme. This covered an initial period of five years. The Way to Pelindaba is an illustrated description of the main activities during that period $1959-64 *$.

The programme called for both electric power production by nuclear fission, and for radioisotope and radiation applications, and necessitated the provision of a nuclear reactor for research and a suitably located research centre. It was decided, in 1960 , to construct a $20-\mathrm{MW}$ high-flux light water moderated and cooled reactor of the Oak Ridge type, suitable for materials testing and for operation initially at about $5 \mathrm{MW}$. A contract for the supply of $S A F A R I$-1 (South $A$ frican Fundamental $A$ tomic Reactor Installation) was signed with the authoritios of the United States. A site, on a farm formerly known as Wilgegund, was chosen for the nuclear research centre, and named Pelindaba, from the Bantu pelila indaba, meaning 'the discussions are finished'. Construction commenced in July 1961, and two years later, in July 1963 , the administration building and part of the reactor building were occupied. The chemistry building, the Van de Graaff accelerator building, the water purification

* South African Atomic Energy Board. Brochure No. 1: The Way to Pelindaba. Pp. 28. Brochure No. 2: Pelindaba-National Nuclear Research Centre of the South African Atomic Energy Board. Pp. 31. (Pretoria: South African Atomic Energy Board, 1964.) works and a portion of the reactor engineering building were completed by the end of 1963. Unfortunately, accidental damage to the reactor vessel of $S A F^{\prime} A R I$ in the United States during test delayed its delivery to South Africa, but the repaired vessel eventually arrived on Christmas Day 1963 and by March 1964 it was installed, together with most of its heavy concrete shield, within the reactor building. The Van de Graaff acceleratora 3-MeV high-intensity beam typo-which provides a source of mono-energetic neutrons, with pulsing if required for the time-of-flight method, has also been erected and is now in commission. A detailed description of the site and layout of the nuclear research contre, together with diagrams of the site buildings, the accelerator and reactor, is given in the companion booklet Pelindaba (Brochure No. 2).

It is well known that South Africa contains some of the world's largest reserves of uranium and has been one of its largest producers. Indeed, until recently, 17 uranium extraction plants handling about 20 million tons of residue slimes from 26 mines, eight contact-process sulphuric acid plants, and a factory for the conversion of the custard-yellow cream emanating from the extraction plants were in continuous operation. All forms of refined uranium are produced in substantial quantities, the products including uranium metal, its carbide, trioxide and tetrafluoride, and small quantities of hexafluoride. A pilot plant has been constructed to investigate the production of a nuclear-grade uranium product, containing only a few parts per million of impurity, from the uranium extraction plants at the gold mines at Bufflesfontein. This is known as the Bufflex Project and was started in October 1963.

The research staff of the Atomic Energy Board, some eighty of whom have been trained or are still training at 
nuclear research establishments in some ten countries outside Africa, belong to eight divisions. The Geology Division, though of primary importance, is small, because many of its activities are covered by the Geological Survey Office of the Government. The Extraction Metallurgy Division, which is housed at the Government Metallurgical Laboratory, makes use of the services provided there. The third division which relies on external facilities is the Life Sciences Division, and the number of its staff at Pelindaba is accordingly limited. The remaining five Divisions-Reactor Engineering, Chemistry, Physics, Physical Metallurgy, and Isotopes and Radiation (Protection and Application) - comprise the bulk of the research staff stationed at or attached to the National Nuclear Research Centre at Pelindaba, and at present three laboratory blocks are at their disposal. There are in addition three technical divisions. The Research Reactor Division will operate the reactor $S A F A R I$ for the research scientists; the Technical Services Division undertakes the provision of services such as power, water, compressed air and workshop facilities; and the Liaison and Informa. tion Division is responsible for external relations and the provision of information to the staff and outside bodies.

The final section of the roport deals with future activities. In the late 1970's the world demand for uranium may exceed its availability and consideration may have to be given to low-grade sources of uranium. Rapid developments in enriched uranium reactors have directed attention to enrichment processes in which uranium hexafluoride is of importance, and the production of this particular compound is being investigated, together with that of zirconium, hafnium, thorium and the rare earths. The recovery of beryllium, niobium, tantalum and lithium from deposits of pegmatites is also being investigated. The power reactor project is to be pushed ahead and this will require the evaluation and testing of fuel, materials and components, together with the development of fabrication techniques. Solid-state investigations of irradiation effects and neutron diffraction investigations will be needed, and in order that this work may proceed before the neutron flux from $S A F A R I$ becomes available, a large $\gamma$-radiation source will be installed. The Van de Graaff building is to be extended to accommodate the whole of the expanded Physics Division, and a new library building is to be provided to relieve congestion in the administration building. For the second five-year programme to reach the target figure of expenditure of $R .3$ million per year the Government has trebled its contribution and the Electricity Supply Company its share five-fold. Heavy industry, too, has pledged an amount totalling more than twice its contribution during $1959-64$.

S. Weintroub

\section{PRESERVATION OF RURAL ENGLAND}

$\mathrm{T}$ HE dominant impression left by the thirty-eighth annual report of the Council for the Preservation of Rural England for the year 1963-64* is the magnitudo of the scope there still is for such independent voluntary effort, and the vigilance and vision, as well as the balance and fairmindedness, with which the Council, through its Executive Committee, diligently strives to ensure that harmful development is never allowed without question. Wherever possible, the needs of the countryside as a whole are balanced against what are often private or temporary ends. While the year has brought some evidence of increasing official awareness of the need to look well ahead in planning matters, and in estimating future demands on land and natural resources, the report notes that amendment of the National Parks Act, 1949, is still long overdue, the findings of the Royal Commission on Common Land in 1958 have still to be implemented, and the coast is still subject to piecemeal development and divided control. The circular issued to local authorities by the Ministry of Housing and Local Government in September 1963 emphasized the need for positive planning of coastal areas. It is welcomed, but it is regarded as being too local in scope. What is needed is a national policy for the preservation of the countrysido based on a Land Budget, allotting land used according to definite patterns of priority.

The Council is sympathetic to the difficulties of the Central Electricity Generating Board and recognizes that sites for power stations are hard to find, and that there is still a formidable gap between the cost of overhead and underground transmission. The generation, transmission and distribution of electricity present the Council and the planning authorities with difficult problems, and the concern expressed in this report, espccially with regard to ovorhead lines, will not be diminished by the subsequent decision of the Minister of Power to disregard the recommendations of his own inspectors and the objections of all the local authorities concerned and allow the Central Electricity Generating Board to run a supergrid power line in 160-ft. pylons over the Sussex Downs. The timing

* Council for the Preservation of Rural England. Thirty-eighth Annual Countil for the Preservation of Rural England, 1964.) of the announcement to coincide with the parliamentary recess may well have justified the Council in thinking that the scales are weighted against amenity and that there is substance in Lord Chorley's suggestion that the replacement of the Ministry of Town and Country Planning by one of Housing and Local Government represents more than a change of name and results in a situation in which decisions against amenity are taken by one who judges his own cause. On water undertakings the Council is convinced that traditional sources of water are likely to prove inadequate before long and that a national water grid will be needed. Major reliance will eventually be placed on the distillation of sea-water and the re-use of water. It points out that the Minister of Housing and Local Government himself agrees that the Conference on Water Supplies in the north-west dismissed the distillation of sea-water too lightly.

The Council has made constructive proposals concerning many road projects. It welcomes the Buchanan Report and the South-East Study, as well as the proposals put forward towards the end of 1963 by the Standing Conference on London Regional Planning under the title Population, Employment and Transport in the London Region: Meeting the Situation, but the report stresses the need for research into every aspect of life in towns, of movement between towns, and of their relations with one another. This involves the consideration of regional groupings and, beyond these, of national problems. Concern is expressed at the shortage of qualified planning staff, and the Council is profoundly disturbed as to the future of the 'Green Belts', on which it finds the Minister's attitude disturbing, in spite of an explicit statement that the Government has no intention of abandoning the Green Belt policy.

Inevitably, much of the report is concerned with comments on particular topics, but the broad subjects covered-including rural housing, litter and refuse disposal, commons and open spaces, nature conservation, trees, national parks, preservation of buildings, the siting of radio and telovision stations, caravan and camping sites, oil pollution of the sea, mineral undertakingsillustrate its wider range of interests and the many spheres in which it has been called on for advice or action. 